\title{
Philip Sidney's Stella: The Lady, the Countess, and the Queen
}

\author{
Saleh H. Alkharji ${ }^{1}$ \\ ${ }^{1}$ Faculty at English Language Institute, King AbdulAziz University, Jeddah, Saudi Arabia \\ Correspondence: Saleh H. Alkharji, King AbdulAziz University, ELI, Jeddah, Saudi Arabia. E-mail: \\ Salhamad.ms@gmail.com
}

Received: March 7, 2021 Accepted: April 22, 2021 Online Published: May 17, 2021

doi:10.5539/ells.v11n2p50 URL: https://doi.org/10.5539/ells.v11n2p50

\begin{abstract}
In his poetic sequence, Astrophil and Stella (1591), Philip Sidney dramatizes his speaker's romantic ambitions of climbing the Ladder of Love. While many academics interpret the sequence as a semi-biographical work, they disagree in evaluating how deep the sequence mirrors Sidney's life. Traditionally, Astrophil is interpreted as a surrogate for Sidney and, more critically, Stella is read as a fictionalized version of Lady Rich. However, given the inconsistency of literary evidence, a new reading of the sequence emerged and argued that Stella is Sidney's wife, Frances Walsingham. Although this paper agrees on the surrogacy of the speaker in the sequence, a closer analysis of the poetic language used in Sidney's sonnets would contradict these Stella's interpretations. Furthermore, as this paper cites historical documents that confirm the non-romantic relationship between Philip Sidney and Lady Rich, a closer examination of the sequence and the historical context of the Elizabethan Era would conclude that Stella's real identity is far more complex and multidimensional than to be a mere fictionalized version of Lady Rich or Frances Walsingham. In fact, an investigation of Sidney's personal life and a close reading of Astrophil and Stella would conclude that Sidney's Stella is a masked version of Queen Elizabeth.
\end{abstract}

Keywords: Elizabethan Era, Philip Sidney, platonic love, English Renaissance poetry, Astrophil and Stella

\section{Introduction}

Understanding how poets navigated the political climate during the Elizabethan Era (1558-1603) is crucial in analyzing their works. For socioeconomic reasons, poets during the Elizabethan Era frequented the royal court. Some of them were outsiders, and others were elite aristocrats whose heritage permitted them to occupy a role in the royal court. However, that role was not fixed; it shrank and widened-depending on the circumstances (Greenblatt \& Abrams, 2006, p. 481). Thus, many courtiers fought to expand their role(s) using their fortunes, assets, and talents - especially literary talents. Given the Elizabethan political climate, many courtiers disguised their gratitude, love, frustration, regrets, and disappointments through their works (Greenblatt \& Abrams, 2006, p. 482). Chief among them was Philip Sidney, whose work in Astrophil and Stella (1591) serves as an exemplum of how a courtier deployed his talents to empower his position.

While Sidney's sequence depicts Astrophil's attempts of reaching his lover, his sonnets draw direct, as well as indirect, parallels between his own life and his speaker. In other words, to read the sequence through a romantic literal lens is to simplify Sidney's works and ignore the historical context of the Elizabethan Era. In a way, Sidney modifies the Platonic concept of the Ladder of Love and employs it to express his social and political ambition of transcending the declining-status of his social life by romanticizing, or dramatizing, a failing love story between his speaker and Stella. While many critics and scholars agree that Astrophel is a mouthpiece for Sidney (i.e., Stillinger, 1960; Marotti, 1982; Banks, 1935), they disagree on who is the real Stella. In this paper, I argue that Stella is non-other than Queen Elizabeth.

\section{Historical Context}

Although this paper's goal is not Sidney's biographical history, the premise of this paper relies heavily on the historical context of the Elizabethan Era - a historical period in which Sidney, as a Courtier and a Poet, thrived and moribund. During the Sixteenth Century, the English throne played a critical role within society and had an incomparable impact on people's life (Greenblatt \& Abrams, 2006, p. 486). That role significantly transformed the royal court into a battleground, where the upper class fought to gain power, protect their status, and minimize the influence of their rivals. To Sidney, and other poets, the court held another dimension of significance-it was 
"the center of culture as well as power" (Greenblatt \& Abrams, 2006, p. 486). Poets, playwrights, lyric-writers aspired to employ their skills and talents to be courtiers and fulfill their ambitions of establishing themselves as members of the upper-class society. During that period, England was an absolute monarchy, in which the throne occupier enjoys a wide range of institutionalized power that surpassed the judicial authority and, later, the church authority (Greenblatt \& Abrams, 2006, p. 481). For that reason, the "Tudor courtiers were torn between the need to protect themselves and the equally pressing need to display themselves" (Greenblatt \& Abrams, 2006, p. 487). In other words, English writers, who aspired to show their literary talents, structured their works, crafted their stories, and composed their writings cautiously and carefully so they could avoid disturbing the throne. As a result, more often than not, English writers, who wanted to express their disappointments or criticisms, resorted to employing allegorical and metaphorical devices to speak their minds - and Sir Philip Sidney was undoubtedly one of them.

Many scholars argue that Astrophil is a fictionalized speaker who was employed to serve "primarily [as] an allegory of court politics" (Wilson, 1991, p. 313). Furthermore, when Sidney was working on Astrophil and Stella, he was more likely to have written the sonnets separately on different timeframes (Banks, 1935, p. 408; Stillinger, 1960, p. 619). Then, he revised them and restructured them into one semi-united sequence (Banks, 1935, p. 408; Stillinger, 1960, p. 619). Economically, Sidney could not sustain his fortune and wealth-although he had hoped to inherit his uncle's Leicester estates, his uncle, unpredictably, had a son with his mistress (Marotti, 1982, p. 400). Politically, his diplomatic ambition was cut short as he was labeled, by his rivals in the court, as "an irresponsible radical Protestant"-which led Queen Elizabeth to believe that he is "unfit for major office" (Marotti, 1982, p. 400). In fact, for years, Sidney had been denied the honors he had hoped to achieve through "merit, service, and birth" (Marotti, 1982, p. 400). Socially, although he enjoyed a status of a knighthood, Sidney is believed to be humiliated publicly in an infamous tennis court quarrel with the Earl of Oxford-an incident that he alludes to in "sonnet 41" (Marotti, 1982, p. 403). This incident exemplified Sidney's social status and implied that he "could not bear the weight of his aspirations" (Marotti, 1982, p. 403). In short, Sidney's declining economic, political, and social status made him aware of the disparity between himself and the aristocratic class, which motivated him to employ different approaches to bridge that gap-from writing poetry to give presents to Queen Elizabeth.

In 1581, Philip Sidney, then-a-veteran courtier, presented a jewel to Queen Elizabeth as his New Year's gift (Minogue, 1996, p. 555). During that time, not everyone was able to offer gifts to the throne (Greenblatt \& Abrams, 2006, p. 482). In fact, if the Queen allowed a courtier to exchange gifts with her, it would be understood as a favor from the Queen (Minogue, 1996, p. 555). To Sidney, the Queen's acceptance of his gift marked an end of his decaying status as "a court hanger-on" and meant that he resumed his old position as a courtier (Minogue, 1996, p. 555). To explain, as a single woman who occupied the Tudor Throne, Queen Elizabeth was the center of marriage proposals that flood her court. While many of these proposals (the vast majority, in fact) failed from the beginning, a few of them were close to succeeding - one of the few proposals came from Francis, Duke of Alençon (Minogue, 1996, p. 555). However, Sidney opposed the proposal and pressed "too strongly the case against Elizabeth's possible marriage to Alençon" in a letter that somehow went public in 1579 (Minogue, 1996, pp. 555-556). Because of the letter, Sidney was "banished from the Court" from 1579 to 1581-a period which is believed that he started composing Astrophil and Stella (Minogue, 1996, p. 555). Literary historians believe that Sidney's gift to the Queen was “witty, coded self-abasement" and recognition of Elizabeth's power over him (Minogue, 1996, p. 555). More important, Sidney's gift to the Queen and his opposition to Alençon's proposal is indicative of the unusual closeness of the ambiguous relationship Sidney enjoyed with Queen Elizabeth. The nature of that relationship was yet to be defined - due to the fashion of the royal court during the $1580 \mathrm{~s}$, in which the multidimensional relationship(s) between a courtier and the Crown is multilayered. However, in sonnets 9, 23, 27, and 30, a glimpse of this relationship between Sidney and the Queen is implied.

Sidney's speaker situates Stella to be the object, as opposed to the subject, of his speech in Astrophil and Stella - a semi-traditional approach to the Petrarchan poetry. The employment of this rhetorical situation allows Astrophil to shape our perspective(s), as his audience, through his narrowed narration/articulation. As some critics put it, "[w] hether he writes a solitary meditation, an epistle to Stella, or a defense to outsiders of his love, he controls the experience" of his readers (Jones \& Stallybrass, 1984, p. 54). There are two approaches to interpret Sidney's employment of this rhetorical situation: First, if the lines are to be blurred between the speaker and Sidney himself (as it will be explained later), Sidney wants to take control and resort all the power within his voice - as though he paradoxically switches position between reality and fiction. To illustrate, during the period from 1579 to 1581, Sidney realized that he is powerless in front of the Queen, in which his gift to the Queen marked his recognition for "the need for submission to the Queen before all else" (Minogue, 1996, p. 557). In 
fact, he wrote a letter to a friend, in which he "laments his loss of voice with the Queen" (Minogue, 1996, p. 557). Second, he situates Stella to be the object for practical reasons since the speaker is the one who will undergo a journey of transcending while Stella is already positioned as a transcendent-figure. Now, to contemplate the thesis of this paper, it is crucial to illustrate who Stella is, how she is depicted, and for what reasons Astrophil aspires to join her.

\section{Analysis}

While Stella's real identity has been the center of various debates, many scholars agree on two significant interpretations: (1) Sidney employed a historical, or a real-life, figure named Penelope Devereux, otherwise known as Lady Rich, to be the model of his Stella (among those scholars are Arber and Buxton); (2) others have argued that Stella is based on Sidney's wife, Frances Walsingham, (this interpretation inspired by Spenser's Colin Clouts Come Home Againe). Before presenting my argument that Stella is Queen Elizabeth, it is crucial to dispute these two interpretations first.

In his introduction to Sidney's sonnet, Edward Arber claimed that "Lady Penelope Devereux, eldest child of Walter, 2nd Earl of Essex; and elder sister to his successor Robert, the second favourite of Queen Elizabeth: was Sir Philip Sidney's first and only love, his Stella." (qtd. in Stillinger, 1960, p. 617, emphasis added). This interpretation is echoed by John Buxton who declared that there is "no doubt Stella represents Virtue in many sonnets as well as Beauty; but she also represents Penelope Devereux." (Buxton, 1987, p. 164). There were two reasons to support this argument: (1) The frequent mention of Rich, Penelope's last name after her marriage, in Astrophel and Stella; (2) the long relationship between Sidney and Penelope's family.

As mentioned earlier, Penelope Devereux was known, at least for while, as Lady Rich because she married a man named Robert Rich and took his last name (Stillinger, 1960, p. 618). At first, it seems appropriate to link Stella to Lady Rich. Still, upon a closer examination of literary devices and historical context, it would become clear that Sidney uses "Rich" as a pun in his sequence. For example, in sonnet 24, Sidney writes:

Rich fools there be, whose base and filthy hart

Lies hatching still the goods wherein they flow:

And damning their own selves to Tantal's smart,

Wealth breeding want, more blest, more wretched grow.

Yet to those fools heav'n such wit doth impart,

As what their hands do hold, their heads do know,

And knowing love; and loving lay apart,

As sacred things, far from all danger's show.

But that rich fool who by blind Fortunes lot,

The richest gem of Love and life enjoys,

And can with foul abuse such beauties blot;

Let him, deprived of sweet but unfelt joys,

(Exil'd for aye from those high treasures, which He knows not) grow in only folly rich. (1-14)

While it's possible that Sidney ridicules Lord Rich as a "rich fool" in line 9, the wordplay is more evident in lines 10 and 14, where he puns the name as "rich" or "richest." The usage of "Rich" as puns becomes clearer in Sonnet 37:

My mouth doth water, and my breast doth swell,

My tongue doth itch, my thoughts in labour be:

Listen then, Lordings, with good ear to me,

For of my life I must a riddle tell.

Toward Auroras Court a Nymph doth dwell,

Rich in all beauties which mans eye can see:

Beauties so far from reach of words, that we

Abase her praise, saying she doth excel: 
Rich in the treasure of deserv'd renown,

Rich in the riches of a royal hart,

Rich in those gifts which give th'eternal crown;

Who though most rich in these and every part,

Which make the patents of true worldly bliss,

Hath no misfortune, but that Rich she is. (1-14)

Although "Auroras Court" in line 5 is perhaps a reference to Lord Rich's estate in Essex, the repeated uses of "rich" in lines 9-11 is nothing but a wordplay (Stillinger, 1960, p. 625). As Theodore Banks points out, Sidney wanted to imitate his contemporaries given the Elizabethan fondness for puns (Banks, 1935, p. 410). Sidney had "only to provide Stella with a rich husband" for the pun to work (Banks, 1935, p. 410). Furthermore, throughout the sequence, Sidney's speaker struggles to reach his unattainable Stella, which is quite different from Sidney's relationship with Penelope, as historical documents show.

In August 1576, the Earl of Essex, Penelope's father, wrote to Philip Sidney and urged him to visit him after he had fallen ill (Stillinger, 1960, p. 622). Although Sidney failed to arrive in time, the Earl of Essex had left him a message before he died:

"I wishe him well, and so well that if God so move both theire hartes I wyshe that he might matche with my Daughter. I call him sonne, he so wyse, vertuous and godlye, and if he go on in the Course he hath begonne, he wil be as famouse and worthie a gentleman as ever England bredd." (qtd. in Stillinger, 1960, p. 622).

Months later, Edward Waterhouse, the former secretary to the Earl of Essex, wrote to Sir Henry Sidney:

"All thes[s] Lords that wish well to the Children [of Essex], and, I suppose, all the best Sort of the English Lords besides, doe expect what will become of the Treaty between Mr. Phillip, and my Lady Penelope." (qtd. in Stillinger, 1960, pp. 622-623).

From these documents, we understand that Penelope's father admired Philip Sidney and, more importantly, there was a "treaty" of a proposed marriage between Sidney and Penelope, which begs the question: If there was an existing marriage proposal between Sidney and Penelope, why would Philip Sidney base Stella, who was presented in the sequence as an unattainable lover, on Penelope?

Furthermore, as Stillinger points out, academics who supported this view failed to present valid historical evidence of a love affair between Philip Sidney and Penelope Devereux (Stillinger, 1960, p. 638). Equivalently, the same argument could be made against interpreting Stella as Frances Walsingham, Sidney's wife, also known as the Countess of Clanricarde.

Penelope Devereux was traditionally thought of as the inspiration for Stella until the publication of two elegies by Spencer and Lodowick Bryskett in 1595, nine years after Sidney's death (Stillinger, 1960, p. 630). Both these elegies "identify" Stella with Sidney's widow (Stillinger, 1960, p. 630). However, some critics have argued that Spencer, a friend to Sidney, was only trying to "cover-up" for his friend's misbehavior by publishing these two poems (Stillinger, 1960, p. 630). More importantly, a closer reading of the sequence would conclude that Frances Walsingam cannot be Stella.

In Sonnet 45, Astrophel claims that Stella refused to believe him and ignored all the evidence of his love:

Then think, my dear, that you in me do read

Of lover's ruin some sad tragedy:

I am not I, pity the tale of me. (12-14)

Implicitly, in the opening sonnet, where the speaker is in the midst of a conflict between passion and reason, he admits that he knows that he will never win Stella but cannot help but desire her. The correlation between Stella and Sidney's widow is not supported by any reading of the text, which is why "no one has taken it very seriously that Frances is Stella" (Stillinger, 1960, p. 630). Quite the opposite, the text suggests that Stella is based upon someone far more powerful and unattainable to reach.

For instance, the references in the opening line of sonnet 9 imply that Sidney's speaker has a more influential figure in mind than the Lady Rich, the supposed model, or Sidney's wife, as he opens the sonnet with "Queen Virtue's court, which some call Stella's face" (Greenblatt \& Abrams, 2006, p. 977). The personified "Virtue" — which is sandwiched between "Queen" and "court" (1) — serves as a literary and practical mask, in which Sidney disguises the identity of his Stella beneath it (Greenblatt \& Abrams, 2006, p. 977; Minogue, 1996, 
p. 558). Furthermore, "Virtue" can be interpreted as a reference to Elizabeth's virginity, in which Sidney's speaker creates a virtual, or a hypothetical, equation: If Elizabeth is to be married to Alençon (hence, she would lose her virginity), her "Virtue" is to be lost as well (Greenblatt \& Abrams, 2006, p. 977). Profoundly, the speaker hints that the Queen's virginity is interconnected with the Crown's fate-since Elizabeth's "childbearing capacities" could determine the next occupier of the throne (Minogue, 1996, p. 558). The second part of the opening line, "which some call Stella's face" (1), is problematic since it indicates that the speaker wants to distance himself from those "some," which can be only understood as an attempt from Sidney's speaker to continually hide Stella's identity and confuse his audience. In other words, the speaker indicates that Stella in the sonnet is not his Stella - it is the others' Stella, a character who "some" of his readers fictionalized (1). On the other hand, it can also be a symbolic reference Sidney's speaker employs to imply that his Stella has been seen by only "some" (1), which refers to the courtiers. The imagery he uses in the sonnet further depicts an extremely wealthy, as well as powerful, character with a royal prestige as he describes her place, or at least a metaphorical place, as:

The door, by which, sometimes, comes forth her grace,

Red porphir is, which lock of pearl makes sure;

Whose porches rich (which name of cheeks endure),

Marble mixed red and white do interlace. (5-8)

The employment of golden images can be taken literally as a description of Stella's place/Elizabeth's court, in which she "comes forth" through the "[ $t]$ he door" as a mark of her entrance among the courtiers (5). On the other hand, it can be taken as golden "petrifactions of parts of [her] body (hair, lips, teeth)"-respectively (Minogue, 1996, p. 558). Significantly, the speaker concludes this sonnet with an indication that he is "touch[ed]" as he employs Sprezzatura - a rhetorical term that describes "the well-practiced naturalness, the rehearsed spontaneity, which lies at the center of convincing discourse of any sort" (Lanham, 1991, p. 143) —in which he repeats "touch" five times. The repetition means that he is touched "emotionally, physically/sexually, [and] personally," without actually being touched (Minogue, 1996, p. 558). In other words, he is metaphorically touched/affected by a woman who cannot be touched (Minogue, 1996, p. 558; Marotti, 1982, p. 402). Hence, although the untouchable woman can be understood as a direct reference to Stella, who resists any physical contact with Astrophil, it can also be seen as an allegorical reference to a more powerful woman that imposes a wall between her and the speaker.

On the other hand, there is a spiritual glimpse, or a less-materialistic spot, that we encounter in line 9 , in which the speaker describes Stella as a "heavenly guest" (9). Hence, the speaker identifies Stella with her soul, in which her body is troubled — or saved, depends on how we look at it — with its temporality. To him, Stella is more than what it appears on the surface, in which the depth of her soul creates new dimensions to the external appearance of her body. Critics, like Minogue and others, argue that Sidney's speaker in this line sees Stella through a religious lens, which can be interpreted as Elizabeth's role within the Anglican Church (Minogue, 1996, p. 558). However, this interpretation falls short since the religious references, or the biblical language, are barely employed in this sonnet. In addition, the speaker's "heavenly guest" is not necessarily a religious one-it is, more likely, a defensive line. In other words, while Sidney's speaker implies that he sees a side in Stella that no one else does, he also defends his love to her as though it is not related to the materialistic aspects within her. In the case of Queen Elizabeth, his love for her is not of a "political self-serving" nature, which is the most persistent theme of Sonnets 23 and 27 (Marotti, 1982, p. 401).

While the speaker opens sonnet 23 with a direct reference to his critics, "The curious wits" (1), who interpret his love as a political-motivated approach, this sonnet also refers to "the normal attitude of Elizabeth's courtiers" (Marotti, 1982, p. 402), who "judge ambition's rage" (9). Consistently, in lines (5-11), the speaker recites what his critics assumed the reasons behind his sadness and disappointment(s):

Some, that know how my spring I did address,

Deem that my Muse some fruit of knowledge plies;

Others, because the Prince my service tries,

Think that I think state errors to redress.

But harder judges judge ambition's rage,

Scourge of itself, still climbing slippery place,

Holds my young brain captived in golden cage. (5-11) 
First, they think his poetry and "Muse" (6) have misguided him to waste his youth, his "spring" (5), on poetry. Second, they lament his luck as he is given harsh diplomatic crises to solve, in which his "service" to "the Prince" (7) - which is more probably a reference to "the French marriage negotiations" Sidney was tapped to solve (Marotti, 1982, pp. 401-402) - might cause him sadness since he failed to accomplish what he was asked to achieve. Third, the "harder judges" (9) think he is too ambitious compared to his social status and political skills. The last criticism against his ambition is the significant one since it appears in multiple places in Sidney's writings, which indicates that this particular criticism gets under Sidney's skin. For instance, Sidney wrote a letter-probably during the $1580 \mathrm{~s}$ - to his father-in-law, in which he states: "I understand I am called very ambitious and prowd at home, but certainly if thei knew my ha[rt] thei woold not altogether so judge me" (qtd. in Marotti, 1982, p. 402 emphasis added). The criticism against his ambition leads his critics to assume that he employs a Machiavellian plot in his attempt at "climbing slippery place" (10). In other words, they believe that he uses his love for Stella as a way to elevate himself socially, economically, and politically. Hence, Stella can only be seen as Queen Elizabeth since no one can elevate a Knight to a higher social position other than royalty. The poem's pivot comes when the speaker concludes this sonnet with lines that dispute their assumptions as he describes them as "O fools, or over-wise: alas, the race/Of all my thoughts hath neither stop nor start,/But only Stella's eyes and Stella's heart" (12-14). Although many critics read the concluding lines (13 and 14) as a testimony of the speaker's endless love, in which neither its genesis nor its end is known, the line is more rhetorically complicated than that. Structurally, the last two lines could be read differently: it could be read as though the speaker's love "start[s]" (13) with "Stella's eyes" (14) and it "stop[s]" (13) with "Stella's heart" (14). Sidney switches "start [and] stop" (13) to fit the rhyme scheme of the sonnet's structure. It could also be read as though the speaker is preoccupied with Stella, in which she is the beginning and the end-she is the embodiment of time. On the other hand, which is probably the most accurate interpretation, it could be read as an admission from the speaker that although his love "start[s]" with her eyes, it will be stopped by her "heart" (13-14).

The speaker's defense in the concluding lines of Sonnet 23 is mirrored in Sonnet 27, in which Sidney "reconverts the language of ambition into the language of love" (Marotti, 1982, p. 402). In a way, Sidney's pretense of combining ambition and love is paradoxically emphasized through the speaker's denial that his love is pure and without any personal or social agenda. For example, when the courtiers "deem" (4) his love as a "poison foul of bubbling pride" (5), Sidney's speaker spends the last eight lines defending himself against them, in which he responds by admitting that:

But one worse fault, ambition, I confess,

That makes me oft my best friends overpass,

Unseen, unheard, while thought to highest place

Bends all his powers, even unto Stella's grace. (10-14)

However, playfully, the speaker manipulates his admission, in which "ambition" here is not a political one- the one he is being accused of - as much as it is a romantic ambition to reach for "Stella's grace" (10 and 14). As Marotti (1982) puts it, in many of Sidney's sonnets, "[the] lyric [...] emphasizes the conjunction between the political and the amorous" (401). The rhetoric in Sonnet 27 (as well as in sonnet 30) also blurs the lines between Sidney, the historical figure, and his speaker as though the author and his narrator evolved into one being, in which it is hard not to draw parallels that connect the fictional voice to the historical body. For example, in Sonnet 30, the speaker leaves no margin of interpretation as he narrates a semi-political experience that mirrors Sidney's. While the speaker lists political, historical, and religious figures and nations, he reproduces Sidney's own political experience and interests.

One of these political involvements is his diplomatic relationship with "the Dutch" (6), in which Sidney was instrumental in supporting the "Protestant cause" there (Marotti, 1982, p. 401). However, according to Minogue, Sidney situates the Dutch - the Holland Dutch, whose "good towns" (7) were taken by the Catholic Spanish —as a way to illustrate his advocacy for the Protestant cause of his country. In addition, he mentions his "father" (10) and his "golden bit" (9) in the sonnet because he had hoped it will help him "to succeed his father as Elizabeth's Lord Deputy in Ireland" (qtd. in Minogue, 1996, p. 556). Hence, while Sidney's speaker tries to deny his political/social desire and that his love is for itself (without any agenda), here, he reveals part of the truth as he highlights his political ambition, which is "something [...] his coterie readers would have been all too aware [of]" (Marotti, 1982, p. 401).

In short, if the entire sequence of Astrophil and Stella is about love and overcoming sexual desire, why does Sidney's speaker include a sonnet that does not help him advances with the premise of the sequence? Although 
some would answer this question by saying that this part of the journey the speaker undergoes after the Muse told him to "look in [his] heart" (line 14 in Sonnet 1), this answer might condemn the speaker even more. To explain, if the speaker looked in his heart and wrote the sequence accordingly, then it means that his political ambition lies deep in his heart, in which he could not hide it anymore.

To recap, Sidney's refusal of Queen Elizabeth's marriage-proposals is motivated by personal agenda, his disappointment(s) of being marginalized is mirrored in the sequence, and the tension at the Elizabethan Court is depicted in his sonnets through Astrophil, a fictionalized speaker that was used as a device to vocalize Sidney's unachieved-ambition. Ironically, Sidney's political disappointments, declining social status, and failed romantic attempts led him to compose Astrophil and Stella - a poetic and literary masterpiece that enabled him to obtain a historical prestige that no political or social achievements would give him.

\section{Conclusion}

Although his sequence is undoubtedly open for different yet valid interpretations, Philip Sidney's Astrophil and Stella is freckled with a politicized language. While some readings might follow the sexual desire, the love aesthetic, or the rhetorical situations, the reading here tries two things: On one hand, analyzing the sociopolitical context of the period and connect it to the sequence, and on the other hand, tries to explore literature through a historical lens as much as trying to decode the sequence through human motifs. It argued that Queen Elizabeth's situated power is mirrored in Stella's unattainable love - a place that neither Lady Rich nor Frances Walsingham, the Countess, could occupy. More importantly, it concludes that Astrophil's attempt and failure is more of an elaborate metaphor for Sidney's social, economic, and political despondencies.

\section{References}

Ann, R. H. (1964). Astrophel and Stella: 'Why and How.' Studies in Philology, 61(2), 150-169.

Banks, T. H. (1935). Sidney's Astrophel and Stella Reconsidered. PMLA, 50(2), 403-412. https://doi.org/10.2307/458146

Buxton, J. (1987). Sir Philip Sidney and the English Renaissance. Macmillan. https://doi.org/10.1007/978-1-349-19023-2

Greenblatt, S., \& Abrams, M. H. (Eds.). (2006). The Norton Anthology of English Literature. New York: W.W. Norton.

Jones, A. R., \& Peter, S. (1984). The Politics of Astrophil and Stella. Studies in English Literature, 1500-1900, 24(1), 53-68. https://doi.org/10.2307/450349

Lanham, R. A. (1991). A Handlist of Rhetorical Terms. Berkeley: U of California. https://doi.org/10.1525/9780520912045

Marotti, A. F. (1982). 'Love Is Not Love': Elizabethan Sonnet Sequences and the Social Order. ELH, 49(2), 396-428. https://doi.org/10.2307/2872989

Minogue, S. (1996). A Woman's Touch: Astrophil, Stella and 'Queen Virtue's Court. ELH, 63(3), 555-570. https://doi.org/10.1353/elh.1996.0028

Saenger, M. B. (1999). Did Sidney Revise Astrophil and Stella? Studies in Philology, 96(4), 417-438.

Stillinger, J. (1960). The Biographical Problem of Astrophel and Stella. The Journal of English and Germanic Philology, 59(4), 617-639.

Wilson, S. (1991). The Struggle for Sovereignty in Astrophil and Stella. Criticism, 33(3), 309-332.

\section{Copyrights}

Copyright for this article is retained by the author, with first publication rights granted to the journal.

This is an open-access article distributed under the terms and conditions of the Creative Commons Attribution license (http://creativecommons.org/licenses/by/4.0/). 